\title{
Modern pollen and vegetation relationships in the Yili Basin, Xinjiang, NW China
}

\author{
ZHAO KeLiang \& LI XiaoQiang* \\ Key Laboratory of Vertebrate Evolution and Human Origin of Chinese Academy of Sciences, Institute of Vertebrate Paleontology and \\ Paleoanthropology, Chinese Academy of Sciences, Beijing 100044, China
}

Received November 18, 2012; accepted April 16, 2013; published online June 6, 2013

\begin{abstract}
Fifty-six surface pollen samples from different vegetation zones in the Yili Basin, western Tianshan Mountains, Xinjiang were analyzed to examine the relationships between the surface pollen assemblages and the original vegetation. A pollen analysis and a vegetation investigation with a discriminant analysis show that the pollen assemblages greatly differ across disparate vegetation zones. Twelve pollen taxa can be used as significant types for vegetation reconstruction in the basin. These taxa were the most abundant in the surface pollen samples. Cupressaceae pollen percentages were greater than $1 \%$ in Cupressaceae shrubs. More than $5 \%$ of Picea pollen indicates the growth of a Picea forest within $5 \mathrm{~km}$. The subalpine meadow that is distributed widely in the basin is characterized by high content of Artemisia, Chenopodiaceae, Poaceae, Picea, Asteraceae, Taraxacum and Arenaria pollen types. The Artemisia-Chenopodiaceae-Poaceae-Cannabaceae pollen assemblages indicate the presence of montane steppe in the area. Artemisia and Chenopodiaceae pollen dominate the desert steppe and Populus forest. Artemisia pollen percentages were greater than $60 \%$ in the Artemisia desert, whereas Chenopodiaceae pollen percentages exceeded 65\% in the Chenopodiaceae desert. The Artemisia/Chenopodiaceae (A/C) ratios reflect the vertical moisture changes in the Yili Basin. The mean A/C ratios were greater than 1.2 in the subalpine meadow and montane steppe that occupy the humid zone in the basin. These ratios were between 1 and 1.2 in the Cupressaceae shrubs, desert steppe, Populus forest and floodplain meadow. The ratios were less than 0.5 in the Chenopodiaceae desert, which is an arid environment.
\end{abstract}

Tianshan Mountains, Yili Basin, modern pollen and vegetation, discriminant analysis, $\mathrm{A} / \mathrm{C}$ ratios

Citation: Zhao K L, Li X Q. Modern pollen and vegetation relationships in the Yili Basin, Xinjiang, NW China. Chin Sci Bull, 2013, 58: 4133-4142, doi: 10.1007/s11434-013-5896-X

Understanding the relationships between modern pollen and vegetation is a prerequisite for interpreting the fossil pollen records correctly, thereby improving the accuracy of past vegetation types and climate reconstruction [1-5]. Xinjiang is situated in the arid area of central Asia, which has been a hot spot for paleovegetation and paleoclimate research given its fragile ecology and sensitive response to climate change [6-9]. Modern pollen rain studies in Xinjiang have generated much attention over the past several decades [10-18]. Yan and $\mathrm{Xu}$ [12] reported the characteristics of modern pollen distribution in different vegetation zones in the Altai Mountains. Weng et al. [13] investigated the relationships between surface pollen assemblages and the vege-

*Corresponding author (email: lixiaoqiang@ivpp.ac.cn) tation zone as well as the significance of the Artemisial Chenopodiaceae (A/C) ratios from the West Kunlun Mountains. Pan [14] examined the pollen assemblages of different vegetation types from the northern slope of the Tianshan Mountains. Xu et al. [15] discussed the numerical relationship between the main pollen taxa and vegetation coverage from the southern slope of the Tianshan Mountains. Yan et al. [16] and Yang et al. [17] studied the distribution of surface pollen from the source area of the Urumqi River at the Tianshan Mountains. Luo et al. [18] examined the modern pollen distribution and its relationship to vegetation communities in the Xinjiang region, and suggested that the different vegetation formations have unique assemblages that can be statistically distinguished.

The Tianshan Mountains are one of the largest mountain 
ranges in central Asia; as such, the Tianshan Mountains possess a complicated vertical vegetation zone and creates a natural geographic boundary in the Xinjiang region. At present, most modern pollen studies have been reported in the middle and eastern portions of the Tianshan Mountains. However, little research has been conducted on the modern pollen in the western mountains. Yili Basin, one of the places with the most precipitation in the Xinjiang region, lies in the western section of the Tianshan Mountains. Due to its luxuriant forest, meadow vegetation and complete vertical vegetation zone, the basin is an ideal place for modern pollen study. The current study investigates the modern pollen of the different vegetation zones in the Yili Basin to discuss the characteristics of their assemblages and the significance of the $\mathrm{A} / \mathrm{C}$ ratios in the basin. Our aim is to collect basic data to understand the relationships among pollen, vegetation and climate in central Asia.

\section{Study region}

The Yili Basin $\left(42^{\circ} 41^{\prime}-44^{\circ} 50^{\prime} \mathrm{N}, 80^{\circ} 09^{\prime}-84^{\circ} 56^{\prime} \mathrm{E}\right)$ is an intramontane basin in the western section of the Tianshan Mountains in central Asia. This basin has a temperate, semiarid continental climate and is dominated by westerly winds throughout the year. The basin is in a relatively high precipitation zone of Xinjiang due to its exposure to the humid and warm airflow from the west. The mean annual temperature varies from 2.6 to $9.2^{\circ} \mathrm{C}$ depending on the terrain. The mean annual precipitation is between 200 and 500 $\mathrm{mm}$ on the plains but can reach $800 \mathrm{~mm}$ in the middle zone of mountains $[19,20]$. The vertical vegetation zones possess an evident and complete structure. Classified from top to bottom, this structure includes an alpine cushion-like vegetation zone, an alpine meadow zone, a subalpine meadow zone, a montane forest-meadow zone, a montane steppe and a desert zone [21,22] (Figure 1). Details of the vegetation zones in the basin are described below.
(1) The alpine cushion-like vegetation zone occurs between $3000-4000 \mathrm{~m}$ a.s.l. and is dominated by Thylacospermum caespitosum and Potentilla biflora.

(2) The alpine meadow zone occurs between $~ 2800$ $3500 \mathrm{~m}$ a.s.l. and is composed of Cobresia capilliforms, Carex stenocarpa, C. cobressiformis and Polygonum viviparum.

(3) The subalpine meadow zone occurs from 2000 to $2800 \mathrm{~m}$ a.s.l. and is dominated by Alchemilla obtuse, Alchemilla rubens, Geranium pseudosibiricum, Iris ruthenica. Poa аппиа, Cobresia capilliforms, Festuca coelestis and Thalictrum alpinum. Gentiana tianschenica are also abundant in this zone.

(4) Patches of the Picea schrenkiana forest zone combined with steppe or meadow occur on shady and wet mountain slopes between $\sim 1700-2800 \mathrm{~m}$ a.s.l. Helictotrichon pubescens, Festuca rupicola and Helictotrichon tianschanicum dominate the undergrowth plants in the Picea forest.

(5) The montane steppe zone occurs on the piedmont between $\sim 1000-2000 \mathrm{~m}$ a.s.l. and consists predominantly of Stipa kirghisorum, S. lessingiana and S. purpurea. Festuca ovina, Agropyron cristatum, Leymus tianschanicus, Potentilla bifurca are also common in this zone.

(6) The desert steppe zone occurs below $\sim 1200 \mathrm{~m}$ a.s.l. and is dominated by Festuca ovina, Seriphidium transiliense, Bothriochloa ischaemum, S. capillata, S. caucasica, S. sareptana, Kochia prostrate and Ceratocarpus arenarius.

(7) The montane desert zone can be divided into two types: The Artemisia desert (below $\sim 1200 \mathrm{~m}$ ) is dominated by Seriphidium transiliense, Kochia prostrate and Polygonum aviculare; the Chenopodiaceae desert (between $\sim 800-1000 \mathrm{~m}$ ) is dominated by Chenopodium glaucum, Ceratocarpus arenarius, Seriphidium transiliense, Nanopgyton erinaceum and Kochia prostrate.

(8) The Populus forest and floodplain meadow is distributed across the river floodplain and lowland with high groundwater level. The vegetation types include the Populus

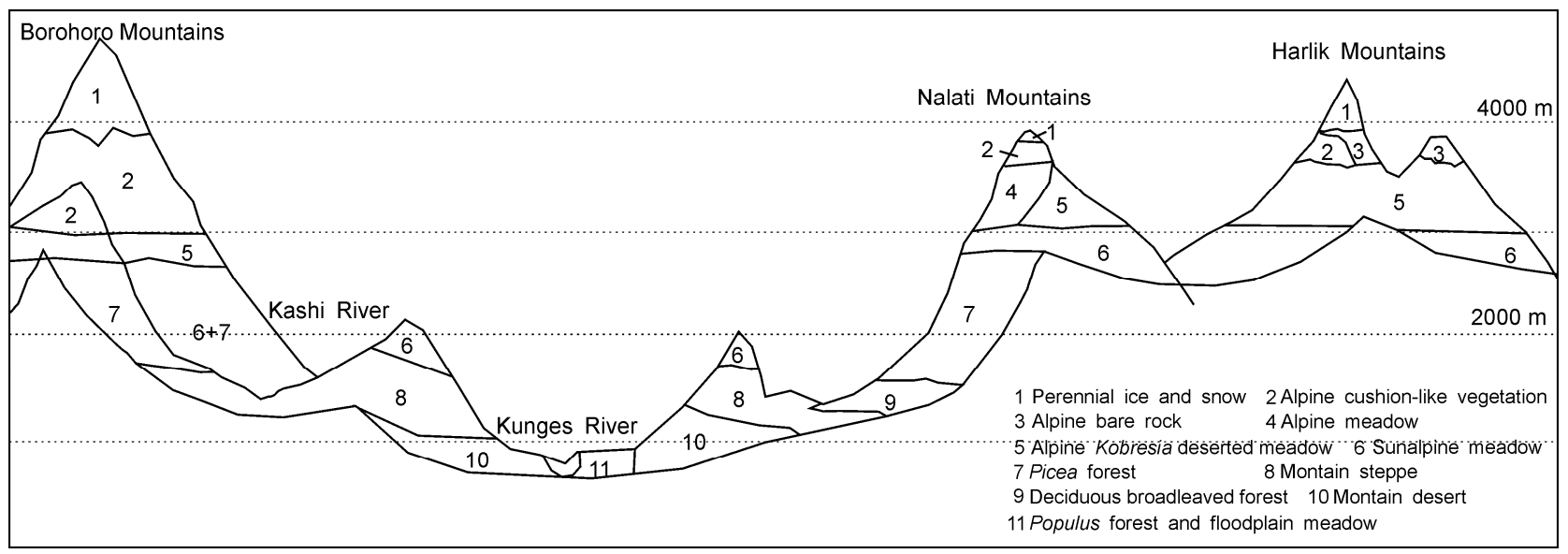

Figure 1 Vertical vegetation zone in the Yili Basin [21]. 
euphratica, Phragmites australis, Achnatherum splendens and Typha communities.

\section{Materials and methods}

Fifty-six topsoil $(0-2 \mathrm{~cm})$ samples were collected from different sites including 3 samples from Cupressaceae shrubs, 5 from the Picea schrenkiana forest, 17 from the subalpine meadow, 12 from the montane steppe, 4 from the desert steppe, 7 from the Artemisia desert, 2 from the Populus euphratica forest and 4 from the floodplain meadow where human disturbance is negligible in the Keguqin, Borohoro and Wusun Mountains (Figure 2). The plot areas of the spruce forest, shrub, steppe or meadow and desert zones are $10 \mathrm{~m} \times 10 \mathrm{~m}, 5 \mathrm{~m} \times 5 \mathrm{~m}, 1 \mathrm{~m} \times 1 \mathrm{~m}$ and $5 \mathrm{~m} \times 5 \mathrm{~m}$, respectively. The samples were collected randomly for each plot.

All 30-g samples were used to prepare the pollen residues in the laboratory. The pollen was concentrated using the acid-alkali-acid method including $10 \% \mathrm{HCl}, 5 \% \mathrm{KOH}$, $40 \% \mathrm{HF}$, acetolysis treatments and sieved through a $7-\mu \mathrm{m}$ screen to remove clay-sized particles [23]. Lycopodium tablets were added to the samples to estimate the pollen concentrations. At least 400 pollen grains using more than two slides were counted in each sample.

Discriminant analysis is an effective method of investigating the quantitative relationship between modern pollen assemblages and vegetation [24-26]. First, the modern samples are divided into different groups consistent with the vegetation types at the sample locations. Then, the discriminant functions are established based on the pollen per- centages in each sample. These functions are used for cross-testing to classify each sample into a different vegetation type to obtain predicted groups. If the predicted result is consistent with the a priori group, then the pollen assemblages are sufficiently representative vegetation types. SPSS 19 was used to perform the discriminant analysis.

\section{Results}

One hundred five pollen taxa were identified across 56 topsoil samples from the Yili Basin. The most abundant arboreal pollen taxa include Pinus, Picea, Betula, Quercus, and Ulmus, and so on. Shrub pollen taxa primarily included $\mathrm{Cu}-$ pressaceae, Salix, Caragana, Ephedra, Hippophae, and so on. Herb pollen types primarily include Artemisia, Chenopodiaceae, Poaceae, Asteraceae, Aster, Taraxacum, Rosaceae, Fabaceae, Geranium, Cyperaceae, Arenaria, Sparganium and Typha, and so on. Pollen percentages are calculated using the sum of the arboreal and non-arboreal pollen (shrub and herb) taxa identified in each sample. The taxa greater than $0.5 \%$ are shown in Figure 3.

\subsection{Modern pollen assemblages across different vegetation zones}

Artemisia (mean 39\%) and Chenopodiaceae (35\%) dominated the modern pollen assemblages from the Cupressaceae shrub zone. However, the Cupressaceae pollen content ranged from $0.4 \%$ to $2.7 \%$, with a mean of $1.4 \%$. The percentages of Picea $(8.3 \%)$ and Poaceae $(2.9 \%)$ pollen

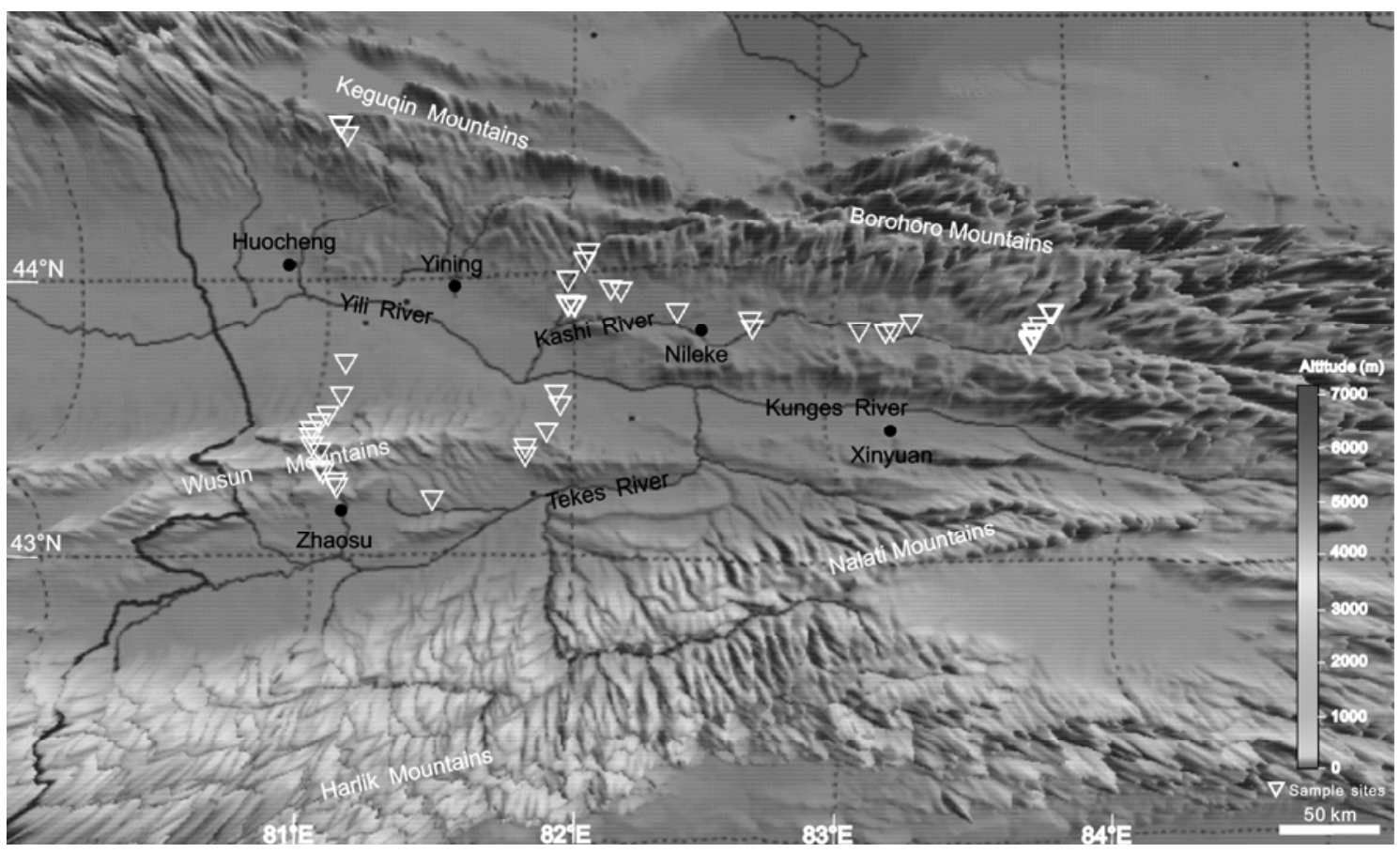

Figure 2 Modern pollen sample sites in the Yili Basin. 


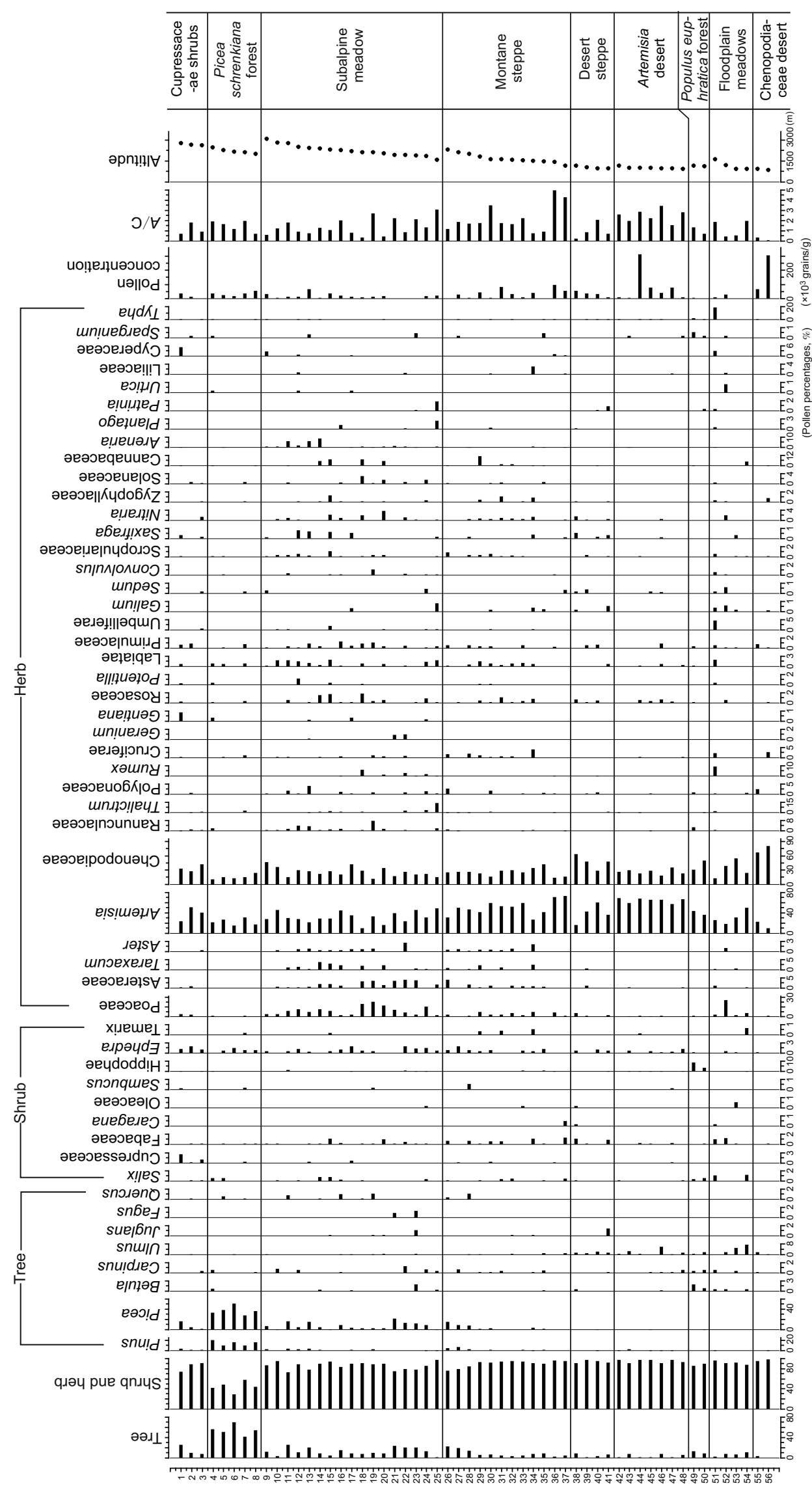


were relative high. The $\mathrm{A} / \mathrm{C}$ ratios range from 0.7 to 1.9 , with a mean of 1.2.

The modern pollen assemblages from the Picea schrenkiana forest were characterized by their high content of Picea pollen (maximum 51.6\%, mean 37.9\%). The mean percentage of Pinus pollen was $14.8 \%$, and the maximum was $20.8 \%$. The Artemisia $(23 \%)$ and Chenopodiaceae $(16.3 \%)$ pollen were relatively low in this zone. The mean percentage of Poaceae pollen content was $1 \%$. The other taxa percentages were less than $1 \%$. The $\mathrm{A} / \mathrm{C}$ ratios ranged from 0.7 to 2 with a mean of $1.5 \%$.

The pollen assemblages of subalpine meadow were characterized by their high content of Artemisia (32.2\%), Chenopodiaceae $(26.8 \%)$ and Poaceae $(9.7 \%)$. The pollen content of Asteraceae, Taraxacum, Ranunculaceae, Thalictrum, Aster, Polygonaceae, Rumex and Arenaria were higher than that of other vegetation types. A few Rosaceae, Lamiaceae, Primulaceae and Saxifragaceae pollens appeared in the samples. Cyperaceae pollen was found in several samples, with a maximum of $2.9 \%$. The Picea pollen maximum content was $7.9 \%$ due to the spruce forest close to the meadow. The $\mathrm{A} / \mathrm{C}$ ratios ranged between 0.4 and 3.1, with a mean of 1.4 .

In the montane steppe zone, the Artemisia pollen percentages $(50.8 \%)$ clearly increased, whereas the Chenopodiaceae $(26.4 \%)$ pollen content changed little compared with the subalpine meadow zone. The maximum Poaceae pollen percentage was $7.9 \%$, with a mean of $3.8 \%$. The Asteraceae (1\%) and Taraxacum $(0.7 \%)$ pollen content decreased. The peak values of Cruciferae, Cannabaceae and Liliaceae pollen content occurred in this zone. The Picea pollen percentages clearly decreased. The $\mathrm{A} / \mathrm{C}$ ratios ranged from 0.8 to 5 , with a mean of 2.2 .

Artemisia (39.4\%) and Chenopodiaceae (47.6\%) dominated the modern pollen assemblages from the desert steppe. The Artemisia pollen content decreased, whereas the Chenopodiaceae pollen content increased compared with the montane steppe zone. The Poaceae pollen percentages (mean $2.7 \%$, maximum $5.7 \%$ ) were relative low compared with the subalpine meadow and montane steppe zones. The Picea pollen content was low with a mean of $0.6 \%$. The maximum Ulmus content was $2.3 \%$, with a mean of $1.7 \%$. The $\mathrm{A} / \mathrm{C}$ ratios ranged from 0.3 to 2.1 , with a mean of 1 .

The pollen taxa from the Artemisia desert zone were homogenous. Artemisia pollen dominated the pollen assemblages $(65.1 \%)$, and the Chenopodiaceae pollen percentage was only $26.9 \%$. The Poaceae pollen content decreased by a mean of $0.8 \%$. The maximum Ulmus content was $6 \%$ with a mean of $1.8 \%$. The other pollen taxa in this zone were less than $1 \%$. The $\mathrm{A} / \mathrm{C}$ ratios ranged from 1.6 to 3.5 with a mean of 2.5 .

Artemisia (40.4\%) and Chenopodiaceae (41.4\%) dominated the modern pollen assemblages from the Populus forest. The mean content of Hippophae pollen was $6.2 \%$, whereas the same value of Typha was $2.1 \%$. The maximum
Ulmus pollen percentage was $2.1 \%$; however, no Populus pollen was found in this zone. The $\mathrm{A} / \mathrm{C}$ ratios ranged from $0.7 \%$ to $1.4 \%$ with a mean of 1.1 .

Artemisia (31.6\%) and Chenopodiaceae (33.6\%) also dominated the modern pollen assemblages from the floodplain meadow. In the Phragmites meadow, the pollen percentages of Poaceae, Asteraceae and Aster were 25.9\%, $1.2 \%$ and $1 \%$, respectively. In the Typha community, the eponymous pollen percentage was $19.2 \%$; in addition, the percentages of Rumex (9.4\%), Thalictrum (2.4\%), Cruciferae $(2.4 \%)$ and Umbelliferae $(1.8 \%)$ pollen were relatively high. In the Tamarix communities, the pollen content of Ulmus (7.7\%), Salix (1.2\%), Poaceae (5.6\%) and Cannabaceae $(5.1 \%)$ was relatively high, whereas the Tamarix pollen content was only $0.7 \%$. The $\mathrm{A} / \mathrm{C}$ ratios ranged from $0.5 \%$ to $2 \%$, with a mean of 1.2 in the floodplain meadow.

Chenopodiaceae pollen dominated the modern pollen assemblages from the Chenopodiaceae desert with a mean of $74.6 \%$. The mean content of Artemisia pollen was only $17 \%$. A few Ulmus (2\%), Polygonaceae $(2.7 \%)$, and Cruciferae $(3 \%)$ pollens were found in this zone.

\subsection{Discriminant analysis}

Fifty-six samples were divided into nine groups (A-I) depending on the different vegetation zones in the Yili Basin (Table 1). The pollen taxa, whose content comprised more than $2 \%$ of at least one sample, were used for the discriminant analysis. The results of this analysis showed that $98.2 \%$ (55 of 56) of the samples were correctly classified into their original vegetation groups (Table 2), which indicates that the surface pollen from the basin represents the vegetation types well. The first two functions accounted for $72.9 \%$ of the total variance. The samples of Cupressaceae shrubs (A), Picea schrenkiana forest (B), desert steppe (E), Populus euphratica forest (G), floodplain meadow (H) and Chenopodiaceae desert (I) can be clearly discriminated using the first two functions (Figure 4). However, group centroids of subalpine meadow (C), montane steppe (D) and Artemisia desert (F) are close to each other, which might be

Table 1 The surface pollen groups for the discriminant analysis in the Yili Basin

\begin{tabular}{lc}
\hline Vegetation type & Group \\
\hline Cupressaceae shrubs & A \\
Picea schrenkiana forest & B \\
Subalpine meadow & C \\
Montane steppe & D \\
Desert steppe & E \\
Artemisia desert & F \\
Populus euphratica forest & G \\
Floodplain meadow & H \\
Chenopodiaceae desert & I \\
\hline
\end{tabular}


caused by the high content of Artemisia pollen in the three vegetation types. Consequently, one montane steppe sample was misclassified as Artemisia desert (Table 2).

\section{Discussion}

\subsection{The relationships between modern pollen assem- blages and vegetation}

This study of 56 topsoil samples from 9 vegetation types indicated that the major pollen taxa in the Yili Basin were Picea, Cupressaceae, Ulmus, Artemisia, Chenopodiaceae, Poaceae, Asteraceae, Taraxacum, Arenaria, Cannabaceae, Hippophae and Typha. These 12 taxa represent the main pollen types in the basin that can be used as the significant pollen taxa for paleovegetation and paleoclimate reconstruction in the basin. Picea pollen dominated the modern pollen assemblages from the Picea schrenkiana forest, whereas Artemisia and Chenopodiaceae pollen dominated other vegetation types including Cupressaceae shrubs, subalpine meadow, montane steppe, desert steppe, Artemisia desert, Populus euphratica forest, floodplain meadow and Chenopodiaceae desert in the basin.

Cupressaceae shrubs, which are dominated by Sabina pseudosabina and Juniperus sibirica, grow on sunny or semi-sunny slope between 2500-3000 m a.s.l. in the basin. Artemisia and Chenopodiaceae dominate the pollen assemblages from Cupressaceae shrubs. This result is might be due to the valley breeze that bring Artemisia and Chenopodiaceae pollen from low to high altitudes in the basin. The presence of Cupressaceae pollen was low (maximum 3\%), which shows that this pollen does not reflect the real proportion of its parent plant in the vegetation zone. Cupressaceae pollen, which appears in Picea forest, subalpine meadow and montane steppe and decreases at low altitudes, only exceeded $1 \%$ in the Cupressaceae shrubs. The surface pollen from the Sabina forest in the western Kunlun Mountains suggested that 5\% Sabina pollen content indicates the presence of a Sabina forest, which shows an underrepresentation of Cupressaceae pollen [13].
Patches of Picea schrenkiana forests are distributed along the shady and wet slopes in the middle mountain region of the Yili Basin. The modern pollen assemblages in the Picea schrenkiana forest are characterized by the high content of Picea, Pinus, Artemisia, Chenopodiaceae and Poaceae pollens, whereas other pollen taxa did not exceed $1 \%$. The Picea schrenkiana forest can be distinguished by the discriminant analysis easily. The content of Picea pollen was greatest in the Picea schrenkiana forest, and decreased with distance from the spruce forest. Picea pollen content comprised more than $5 \%$ of the modern pollen assemblages from the Cupressaceae shrubs and subalpine meadow zones that were less than $5 \mathrm{~km}$ from the Picea forest. This content ranged between $1 \%$ and $5 \%$ in the pollen assemblages from the montane steppe, whose distance ranged from 5 to $10 \mathrm{~km}$. The content comprised less than $1 \%$ of the pollen assemblages from the desert steppe, Artemisia desert and Chenopodiaceae desert, which were more than $10 \mathrm{~km}$ away. The representation and distribution characteristics of the Picea pollen in the Yili Basin were similar to those of other regions in China [13,27-31].

The subalpine meadow, which possesses multiple plant species, is the most widely distributed zone in the Yili Basin. Its plants are primarily composed of Alchemilla, Poa and Stipa with various weeds. Artemisia and Chenopodiaceae dominate the pollen assemblages from the subalpine meadow; however, the abundant pollen taxa and high content of Poaceae pollen (mean 9.7\%, maximum 23.3\%) are most distinctive features in this zone. Rosaceae (especially Alchemilla) is the species that constructs the subalpine meadow; however, the Rosaceae pollen content was low (mean $0.5 \%$, maximum $1.9 \%$ ) and significantly below the proportion of its parent plant. The pollen content of Cyperaceae (maximum 2.9\%) was low due to the few Cyperaceae plants in the subalpine meadow. The characteristics of the pollen assemblages from the subalpine meadow in the basin were similar to those in the western Kunlun Mountains [13].

Stipa and Festuca are constructive vegetation in the montane steppe of the basin. These vegetation coverage and pollen taxa clearly decreased compared with the subalpine

Table 2 The discriminant analysis results of the modern pollen assemblages in the Yili Basin

\begin{tabular}{|c|c|c|c|c|c|c|c|c|c|c|}
\hline \multirow{2}{*}{$\begin{array}{l}\text { Actual } \\
\text { groups }\end{array}$} & \multirow{2}{*}{ Samples } & \multicolumn{9}{|c|}{ Predicted groups } \\
\hline & & A & B & $\mathrm{C}$ & $\mathrm{D}$ & $\mathrm{E}$ & $\mathrm{F}$ & G & $\mathrm{H}$ & I \\
\hline A & 3 & $3(100 \%)$ & 0 & 0 & 0 & 0 & 0 & 0 & 0 & 0 \\
\hline $\mathrm{C}$ & 17 & 0 & 0 & $17(100 \%)$ & 0 & 0 & 0 & 0 & 0 & 0 \\
\hline $\mathrm{D}$ & 12 & 0 & 0 & 0 & $11(91.7 \%)$ & 0 & $1(8.3 \%)$ & 0 & 0 & 0 \\
\hline $\mathrm{E}$ & 4 & 0 & 0 & 0 & 0 & $4(100 \%)$ & 0 & 0 & 0 & 0 \\
\hline $\mathrm{F}$ & 7 & 0 & 0 & 0 & 0 & 0 & $7(100 \%)$ & 0 & 0 & 0 \\
\hline G & 2 & 0 & 0 & 0 & 0 & 0 & 0 & $2(100 \%)$ & 0 & 0 \\
\hline $\mathrm{H}$ & 4 & 0 & 0 & 0 & 0 & 0 & 0 & 0 & $4(100 \%)$ & 0 \\
\hline I & 2 & 0 & 0 & 0 & 0 & 0 & 0 & 0 & 0 & $2(100 \%)$ \\
\hline
\end{tabular}




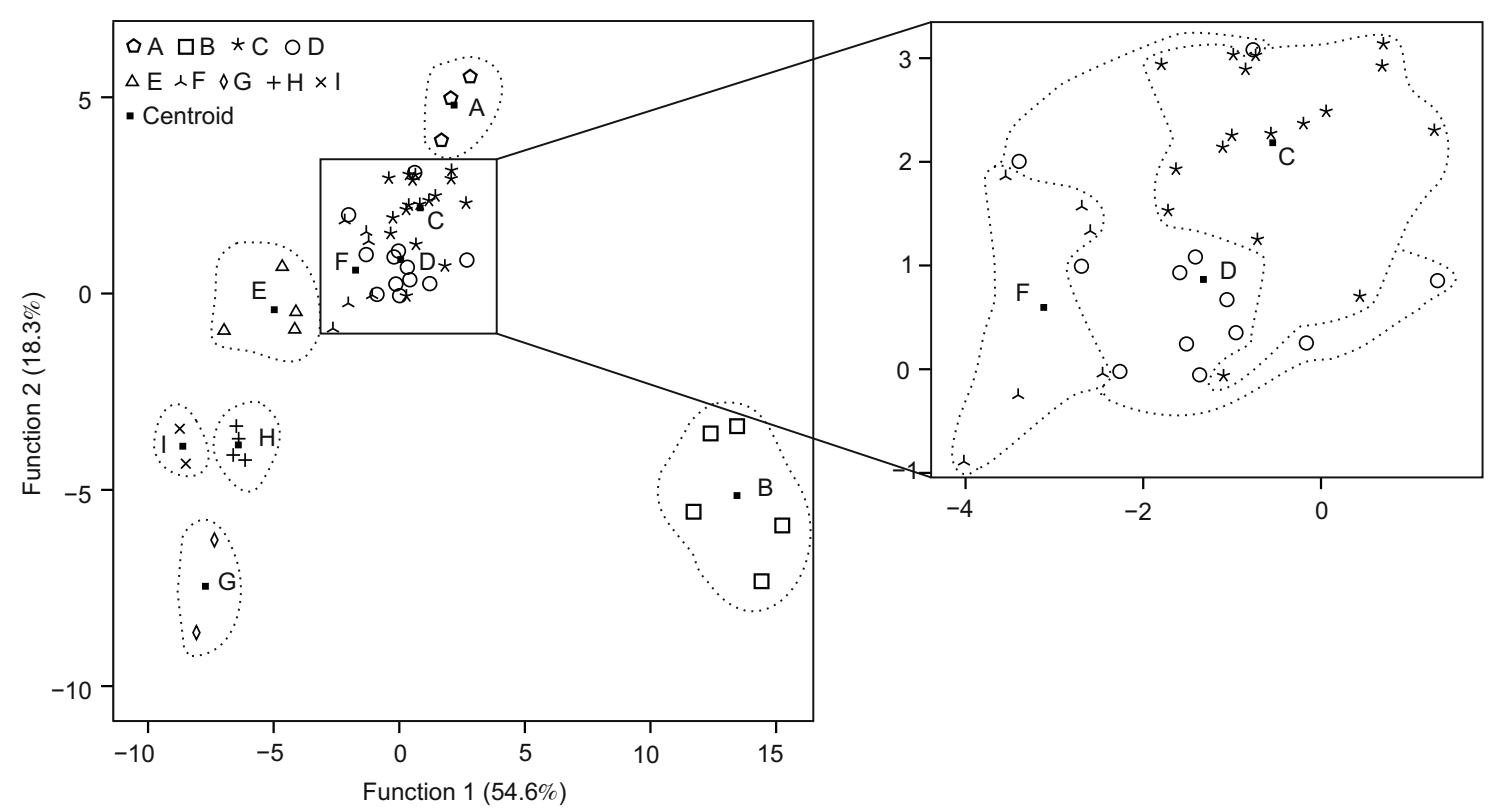

Figure 4 The predicted groups plotted against discriminate functions 1 and 2 for the topsoil samples of the Yili Basin (see Table 1 for vegetation types Groups A-I).

meadow. High contents of Artemisia, Chenopodiaceae and Poaceae characterized these pollen assemblages. The pollen content of Artemisia approximately doubled that of Chenopodiaceae. A valley breeze that brings Artemisia pollen from low to high altitudes most likely causes the high content of Artemisia pollen. The montane steppe flourishes along the south slope of the Tianshan Mountains from 2100 to $2800 \mathrm{~m}$ a.s.l. This area contains more Poaceae pollen (18.9\%) content and less Artemisia pollen (17.8\%) content than the Yili Basin [15]. The different altitudes and climates between the Yili Basin and the south slope of the Tianshan Mountains produce the differences in the modern pollen assemblages from the montane steppe.

The constructive plants in the desert steppe include Stipa, Seriphidium transiliense and Kochia prostrate. The vegetation coverage and pollen taxa reduce in the desert steppe. Artemisia and Chenopodiaceae dominated the pollen assemblages, whereas the Poaceae pollen content dropped below $6 \%$. The pollen assemblages from the desert steppe in the Yili Basin were similar to those of east China, which indicates an overrepresentation of Artemisia and Chenopodiaceae pollen an underrepresentation of Poaceae pollen $[28,30,32,33]$. However, the pollen assemblages from the desert steppe clearly differ between the Yili Basin and the south slope of Tianshan Mountains. The latter contains more Ephedra pollen, which indicates a drier environment [15].

Seriphidium transiliense and Kochia prostrate dominated the plants in the Artemisia desert. Artemisia pollen comprised more than $60 \%$ of the assemblages, whereas Chenopodiaceae pollen comprised less than $30 \%$. The constructive plants in the Chenopodiaceae desert include Chenopodium glaucum, Ceratocarpus arenarius and Seriphidium. The
Chenopodiaceae pollen content exceeded 65\%, whereas Artemisia pollen content comprised no more than $25 \%$, and the presence of other pollen taxa was low. The pollen assemblages from the Populus euphratica forest contained higher content of Artemisia, Chenopodiaceae and Hippophae with few Typha; however, no Populus pollen was found, which indicates that this pollen does not reflect its parent plant coverage [12]. Thin exine wall, low sporopollenin content and consequent rapid oxidization, and a lack of distinguishing features all contributed to the low rate of Populus pollen in the pollen assemblages [34].

The floodplain meadows were primarily distributed in low-altitude areas and depressions of mountain dominated by Phragmites, Typha and Tamarix communities. The Phragmites community contained more Poaceae pollen $(25.9 \%)$ than the subalpine meadow and montane steppe zones. Typha communities are characterized by high content of Typha (19.2\%) and Rumex (9.4\%) pollen that represent the proportions of their parent plants well. The presence of Tamarix pollen was low $(0.7 \%)$ in the Tamarix community, which indicates that Tamarix pollen does not represent its parent plant well [30]. Ulmus pollen (7.7\%) content was high in the Tamarix community; these results are correlated with the growth of Ulmus in the river valley.

\section{2 $\mathrm{A} / \mathrm{C}$ ratios and their climatic significance}

Artemisia and Chenopodiaceae pollen are most important components of the modern pollen assemblages in the Yili Basin. Artemisia and Chenopodiaceae plants were primarily distributed in the low-altitude desert, whereas the montane steppe, subalpine meadow and Cupressaceae shrub zones contained few or no Artemisia or Chenopodiaceae plants. 
However, Artemisia and Chenopodiaceae pollen comprised more than $55 \%$ of the shrubs, meadow and steppe, which suggests that these pollen types are overrepresented. In general, both types represent the ecology of the region, but they do not indicate their parent plants well $[13,30]$. The percentages of Artemisia and Chenopodiaceae pollen decreased as altitude increased in the Yili Basin. Nevertheless, the pollen content of Artemisia or Chenopodiaceae exceeded $30 \%$ in the high-altitude Cupressaceae shrubs due to their high rates of pollen production and the valley breeze in the basin.

EL-Moslimany [35] suggested that the $\mathrm{A} / \mathrm{C}$ ratio is an index of dryness given that greater Chenopodiaceae percentages appear in desert regions, whereas higher Artemisia percentages characterize more steppe-like environments. Later work found that the $\mathrm{A} / \mathrm{C}$ ratios obtained from different vegetation types effectively indicated moisture in arid and semiarid regions in Asia [13,28,33,35-39]. In general, A/C ratios fall below $0.5 \%$ in deserts, from 0.5 to 1.2 in desert steppes, and above 1 in steppes in Xinjiang [40]. These ratios sufficiently indicate moisture levels when the sum of Artemisia and Chenopodiaceae pollens are above 50\% [40]. Because the A/C ratios were below $50 \%$ in the Picea schrenkiana forest, we did not discuss the $\mathrm{A} / \mathrm{C}$ ratios specific to that zone.

The A/C ratios ranged from 0.1 to 5 among the 56 surface pollen samples in the Yili Basin. The minimum ratio was recorded from the Chenopodiaceae desert, whereas the maximum was recorded from the montane steppe (Figure 5). Large fluctuations exist in the $\mathrm{A} / \mathrm{C}$ ratios within same vegetation types; for example, the ratios in subalpine meadow and montane steppe zoned ranged from 0.4 to 3.1 and from 0.8 to 5 , respectively. The $\mathrm{A} / \mathrm{C}$ ratios from the Chenopodiaceae desert were less than 0.5 but greater than 0.5 in all the others. The $\mathrm{A} / \mathrm{C}$ ratios were greater than 1.2 in the wet subalpine meadow and montane steppe zones. The $\mathrm{A} / \mathrm{C}$ ratios were between 1 and 1.2 in the relatively dry Cupressaceae shrub, desert steppe, Populus euphratica forest and floodplain meadow zones; however, these ratios rose to 2.5 in the dry Artemisia desert. When the Artemisia desert was ignored, the $\mathrm{A} / \mathrm{C}$ ratios increased with altitude, peaked in the montane steppe and subalpine meadow zones located in the middle mountain region, then decreased (Figure 5). The $\mathrm{A} / \mathrm{C}$ ratios effectively indicate the vertical moisture changes in the Yili Basin.

Certain studies have shown that human activities can influence $\mathrm{A} / \mathrm{C}$ ratios; for example, the steppe degradation caused by overgrazing increases the number of Chenopodiaceae plants, which decreases the $\mathrm{A} / \mathrm{C}$ ratios $[33,41]$. The modern pollen data from the Yili Basin also revealed the effect of human activities on the A/C ratios; for example, the ratios were below 0.5 in two samples from the subalpine meadow collected at the primary pastoral area of the Kazakhs. In addition, the plant taxa are homogenous in the Artemisia desert, which is dominated by Seriphidium transiliense. This plant produces large amounts of pollen, thereby resulting in higher $\mathrm{A} / \mathrm{C}$ ratios (mean 2.5). Although the habitat of Artemisia desert is wetter than the Chenopodiaceae desert, it is drier than the subalpine meadow and montane steppe. Therefore, caution should be used when interpreting the $\mathrm{A} / \mathrm{C}$ ratios is used to recover the paleoclimate, given the high ratios obtained from the Artemisia desert.

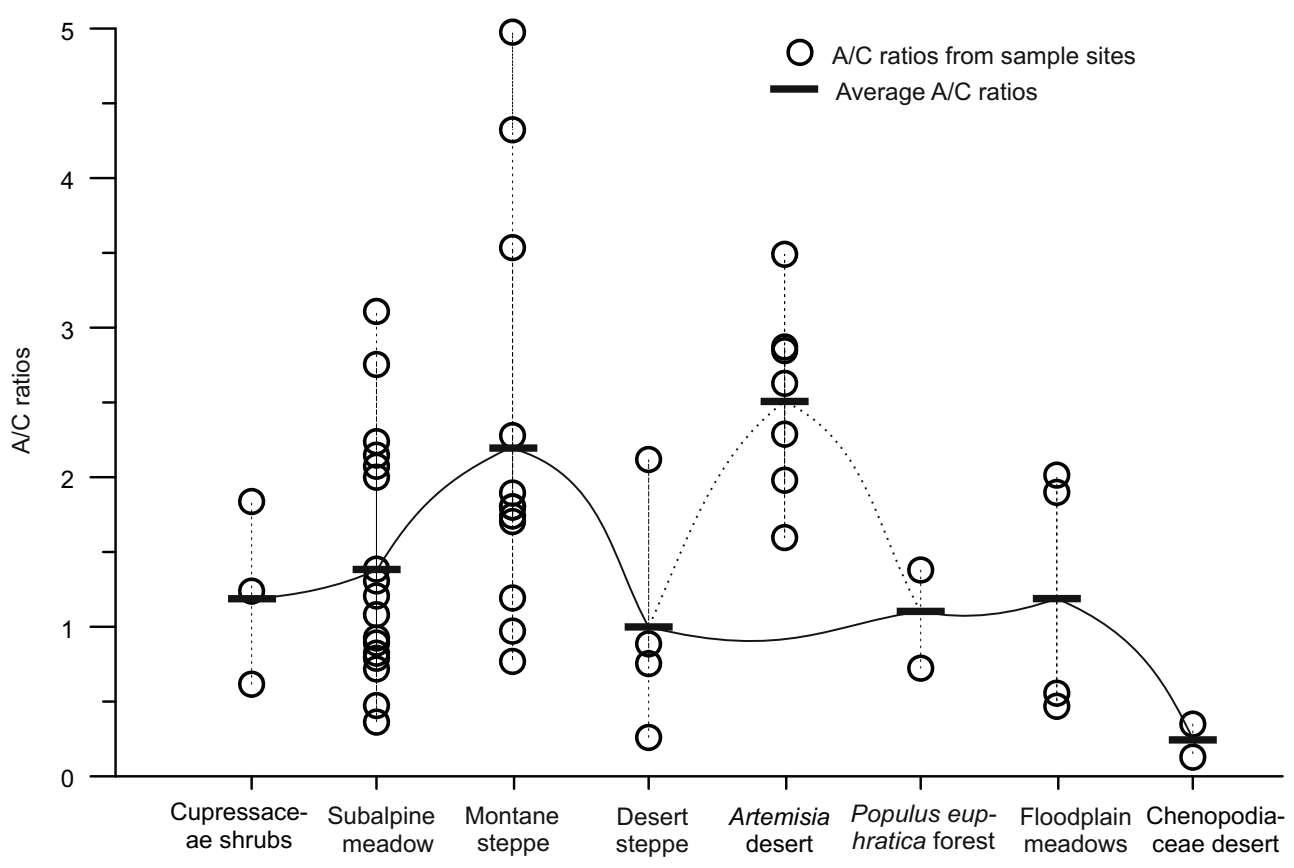

Figure $5 \mathrm{~A} / \mathrm{C}$ ratios from different vegetation types in the Yili Basin. 


\section{Conclusions}

This study investigated nine vegetation zones: Cupressaceae shrubs, Picea schrenkiana forest, subalpine meadow, montane steppe, desert steppe, Artemisia desert, Populus euphratica forest, floodplain meadow and Chenopodiaceae desert. Twelve pollen taxa (Picea, Cupressaceae, Ulmus, Artemisia, Chenopodiaceae, Poaceae, Asteraceae, Taraxacum, Arenaria, Cannabaceae, Hippophae and Typha) are most abundant in the Yili Basin and can be used as the significant taxa for paleoclimate reconstruction in this area. Artemisia, Chenopodiaceae, Picea and Poaceae are the most important taxa among these twelve.

Different vegetation types can be discriminated by applying qualitative and quantitative methods to the pollen assemblages. We confirmed the presence of Cupressaceae shrubs and Picea forest close to the pollen collection site when the pollen percentages were greater than $1 \%$ and 5\%, respectively. Artemisia-Chenopodiaceae-Poaceae-PiceaAsteraceae-Taraxacum-Arenaria pollen assemblages revealed the growth of subalpine meadow. Artemisia-Chenopodiaceae-Poaceae-Cannabaceae pollen assemblages characterized the montane steppe. The desert steppe contained large amounts of Artemisia and Chenopodiaceae pollen contents. The Populus euphratica forest contained large amounts of Artemisia, Chenopodiaceae and Hippophae pollens. Artemisia comprised over $60 \%$ of the pollen content in the Artemisia desert, whereas Chenopodiaceae comprised over $65 \%$ of the pollen content in the Chenopodiaceae desert. Typha and Rumex pollen dominated the Typha community.

$\mathrm{A} / \mathrm{C}$ ratios can effectively indicate vertical moisture changes in the Yili Basin. These ratios were below 0.5 in the dry Chenopodiaceae desert zone and ranged from 1 to 1.2 in the relative dry Cupressaceae shrub, desert steppe, Populus euphratica forest and floodplain meadow zones. The ratios were greater than 1.2 in the humid subalpine meadow and montane steppe zones. $\mathrm{A} / \mathrm{C}$ ratios can climb up to 2.5 in the dry Artemisia desert. A combination of $\mathrm{A} / \mathrm{C}$ ratios and pollen assemblages is necessary to accurately reconstruct paleovegetation and paleoclimate.

We thank John Dodson and Tong Guobang for assisting us with the pollen analysis as well as Liu Hanbin and Gao Qiang for assisting us with fieldwork. This work was supported by the National Natural Science Foundation of China (41102113 and 41172161), the National Basic Research Program of China (2010CB950204) and a MOST Special Fund (KN212431) from the Institute of Vertebrate Paleontology and Paleoanthropology for supporting the project.

1 Aderson P M, Bartlein P J, Brubaker B, et al. Modern analogues of late-Quternary pollen spectra from the western interior of North America. J Biogeogr, 1989, 16: 573-596

2 Zheng Z, Huang K Y, Xu Q H, et al. Comparison of climatic threshold of geographical distribution between dominant plants and surface pollen in China. Sci China Earth Sci, 2008, 51: 582-599
3 Zhao Y, Herzschuh U. Modern pollen representation of source vegetation in the Qaidam Basin and surrounding mountains, north-eastern Tibetan Plateau. Veget Hist and Archaeobot, 2009, 18: 245-260

4 Lu H Y, Wu N Q, Liu K, et al. Modern pollen distributions in Qinghai-Tibetan Plateau and the development of transfer functions for reconstructing Holocene environmental changes. Quat Sci Rev, 2011, 30: 947-966

5 Xu Q H, Tian F, Bunting M J, et al. Pollen source areas of lakes with inflowing rivers: Modern pollen influx data from Lake Baiyangdian, China. Quat Sci Rev, 2012, 37: 81-91

6 Sun J M, Xu Q H, Huang B C. Late Cenozoic magnetochronology and paleoenvironmental changes in the northern foreland basin of the Tianshan Mountains. J Geophys Res, 2007, 112: 1-14

7 Liu X Q, Herzschuh U, Shen J, et al. Holocene environmental and climatic changes inferred from Wulungu Lake in northern Xinjiang, China. Quat Res, 2008, 70: 412-425

8 Chen F H, Yu Z C, Yang M L, et al. Holocene moisture evolution in arid central Asia and its out-of-phase relationship with Asian monsoon history. Quat Sci Rev, 2008, 27: 351-364

9 Li X Q, Zhao K L, Dodson J, et al. Moisture dynamics in central Asia for the last 15 kyr: New evidence from Yili Valley, Xinjiang, NW China. Quat Sci Rev, 2011, 30: 3457-3466

10 Yan S. The characteristics of Quaternary sporopollen assemblage and the vegetation succession in Xinjiang (in Chinese). Arid Land Geogr, 1991, 14: 1-9

11 Yan S. The discussion on the pollen of Pine familiy in surface soil in Xinjiang (in Chinese). Arid Land Geogr, 1993, 16: 1-9

12 Yan S, Xu Y Q. Sporopollen association in surface soil in Altai, Xinjiang (in Chinese). Arid Zone Res, 1989, 6: 26-33

13 Weng C Y, Sun X J, Chen Y S. Numerical characteristics of pollen assemblages of summer samples from the west Kunlun Mountains (in Chinese). Acta Bot Sin, 1993, 35: 69-79

14 Pan A D. Research on sporo-pollen assemblages in surface soil of various vegetation in northern slope of the Tianshan Mountains. Sci Geogr Sin, 1993, 13: 227-233

15 Xu Y Q, Yan S, Jia B Q, et al. Numerical relationship between the surface spore-pollen and surrounding vegetation on the southern slope of Tianshan Mountains (in Chinese). Arid Land Geogr, 1996, 19: 24-30

16 Yan S, Jia B C, Xu Y Q, et al. The surface sampleing of vegetation and pollen in the source area of the Urumqi River (in Chinese). J Glaciol Geocryol, 1996, 18 (Special Issue): 264-273

17 Yang Z J, Kong Z C, Yan S, et al. Pollen distribution in topsoil along the Daxigou Valley in the Headwaters of the Urumqi River, the central Tianshan Mountains (in Chinese). Arid Land Geogr, 2004, 27 : $543-547$

18 Luo C X, Zheng Z, Tarasov P, et al. Characteristics of the modern pollen distribution and their relationship to vegetation in the Xinjiang region, northwestern China. Rev Palaeobot Palynol, 2009, 153: 282295

19 Li J F. Climate in Xinjiang (in Chinese). Beijing: China Meteorological Press, 1991. 1-205

20 Ye W. Characteristics of physical environment and conditions of loess formation in Yili area, Xinjiang (in Chinese). Arid Land Geogr, 1999, 22: 9-16

21 Xinjiang Expedition Team, Chinese Academy of Sciences. Vegetation and Its Utilization in Xinjiang (in Chinese). Beijing: Science Press, 1978. 1-266

22 Editorial Committee for Vegetation of China. Vegetation of China (in Chinese). Beijing: Science Press, 1980. 749-1037

23 Faegri K, Ivrsen J. Textbook of Pollen Analysis. 3rd ed. Oxford: Blackwell, 1989. 295

24 Liu K B, Lam N S N. Paleovegetational reconstruction based on modern and fossil pollen data: An application of discriminant analysis. Ann Ass Am Geogr, 1985, 75: 115-130

25 Reese C A, Liu K B. A modern pollen rain study from the central Andes region of south America. J Biogeogr, 2005, 32: 709-718

26 Li Q, Ge Q S, Tong G B. Modern pollen-vegetation relationship based on discriminant analysis across an altitudinal transect on 
Gongga Mountain, eastern Tibetan Plateau. Chin Sci Bull, 2012, 57: 4600-4608

27 Li W Y. On dispersal efficiency of Picea pollen (in Chinese). Acta Bot Sin, 1991, 33: 792-800

28 Liu H Y, Cui H T, Pott R, et al. The surface pollen of the woodlandsteppe ecotone in southeastern Inner Mongolia, China. Rev Palaeobot Palynol, 1999, 105: 237-250

29 Yan S, Kong Z C, Yang Z J, et al. Seeking relationship between vegetation and Picea pollen in surface soils of Xinjiang, northeastern China (in Chinese). Acta Ecol Sin, 2004, 24: 2017-2023

30 Xu Q H, Li Y C, Yang X L, et al. Quantitative relationship between pollen and vegetation in northern China. Sci China Ser D-Earth Sci, 2007, 50: 582-599

31 Lu H Y, Wu N Q, Yang X D, et al. Spatial pattern of Abies and Picea surface pollen distribution along the elevation gradient in the Qinghai-Tibetan Plateau and Xinjiang, China. Boreas, 2008, 37: 254-262

32 Li Y Y, Zhang X S, Zhou G S, et al. Quantitative relationships between vegetation and several pollen taxa in surface soil from North China. Chin Sci Bull, 2000, 45: 1519-1523

33 Li Y C, Xu Q H, Yang X L, et al. Pollen indication to source plants in the eastern desert of China. Chin Sci Bull, 2005, 50: 1631-1641

34 Campbell I D. Quaternary pollen taphonomy: Examples of differen- tial redeposition and differential preservation. Palaeogeogr Palaeoclimatol Palaeoecol, 1999, 149: 245-256

35 El-Moslimany A P. Ecological significance of common nonarboreal pollen: Examples from drylands of the Middle East. Rev Palaeobot Palynol, 1990, 64: 343-350

36 Huang C X, Van Campo E, Duobuleimei F. A study on pollen in surface soil from the western Xizang (in Chinese). Arid Land Geogr, 1993, 15: 75-84

37 Cour P, Zheng Z, Duzer D, et al. Vegetational and climatic significance of modern pollen rain in northwestern Tibet. Rev Palaeobot Palynol, 1999, 104: 183-204

38 Herzschuh U, Tarasov P, Wünnemann B, et al. Holocene vegetation and climate of the Alashan Plateau, NW China, reconstructed from pollen data. Palaeogeogr Palaeoclimatol Palaeoecol, 2004, 211: 117

39 Shang X, Li X Q, An Z S, et al. Modern pollen rain in the Lake Qinghai basin, Sci China Earth Sci, 2009, 52: 1510-1519

40 Sun X J, Du N Q, Weng C Y, et al. Paleovegetation and paleoenvironment of Manas Lake, Xinjiang, Northwestern China during the last 14000 years (in Chinese). Quat Sci, 1994, 3: 239-248

41 Wang F Y, Song C Q, Sun X J. Study on surface pollen in middle Innermongolia, China (in Chinese). Acta Bot Sin, 1996, 38: 902-909

Open Access This article is distributed under the terms of the Creative Commons Attribution License which permits any use, distribution, and reproduction in any medium, provided the original author(s) and source are credited. 